\title{
Assessing the rock glacier kinematics on three different timescales: a case study from the southern Swiss Alps
}

\author{
Cristian Scapozza, ${ }^{1 *}$ Christophe Lambiel, ${ }^{2}$ Claudio Bozzini, ${ }^{3}$ Stefano Mari ${ }^{4}$ and Marco Conedera ${ }^{3}$ \\ ${ }^{1}$ Institute of Earth Sciences, University of Applied Sciences and Arts of Southern Switzerland (SUPSI), Canobbio, Switzerland \\ 2 Institute of Earth Surface Dynamics, University of Lausanne, Lausanne, Switzerland \\ ${ }^{3}$ Swiss Federal Research Institute WSL, Insubric Ecosystem Research Group, Bellinzona, Switzerland \\ ${ }^{4}$ Department of Geosciences, Geography Unit, University of Fribourg, Fribourg, Switzerland
}

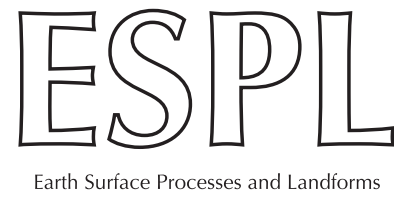

ABSTRACT: Surface temperature increases since the 1990s have often been associated with an increase in the speed of rock glaciers. Evidence of similar links on the centennial to millennial scale are, however, still lacking due to less focus to date on the medium- and long-term kinematics of these landforms. In order to assess (palaeo)climatic variations in rock glacier kinematics, we analysed the movements of the Stabbio di Largario rock glacier in the southern Swiss Alps using three different timescales. The Schmidt hammer exposure-age dating (SHD) was applied to study long-term kinematics in order to extrapolate the minimal age of the formation of the rock glacier, which may have started its development after the Mid-Holocene climate optimum, and to detect possible accelerations of the horizontal surface velocity during the Medieval Warm Period. Georeferentiation and orthorectification of six historical photographs of the rock glacier taken between AD 1910 and today were analysed using monoplotting to detect the rock glacier displacement on the decennial scale from the end of the Little Ice Age. Finally, differential global positioning system (dGPS) monitoring data available since AD 2009 were used to assess annual and seasonal creep rates of the rock glacier at present. Our results show a link between the periods of increase in mean air temperature on different timescales and variations in rock glacier kinematics and provide important new insights into rock glacier development and evolution on the long-term scale. Copyright (c) 2014 John Wiley \& Sons, Ltd.

KEYWORDS: permafrost; rock glacier; monophotogrammetry; Schmidt hammer exposure-age dating (SHD); dGPS

\section{Introduction}

Creeping mountain permafrost landforms such as rock glaciers are important indicators of both former and present geomorphological, climatical and ecological evolution of the Alpine environment (e.g. Barsch, 1996; Haeberli et al., 2006). Classical rock glacier studies have mainly focused on the origin, structure, dynamics and age of these landforms (e.g. Humlum, 2000; Frauenfelder, 2005). Since the early 1990s, advances in technical devices and computing power have allowed their analysis using improved geodetical survey methods (Lambiel and Delaloye, 2004), airborne digital photogrammetry (Kääb, 2005), and terrestrial laser scanning and space-borne radar interferometry (Strozzi et al., 2004). Such studies suggest increases in rock glacier velocities as a consequence of higher surface temperature (e.g. Kääb et al., 2007; Delaloye et al., 2008; Bodin et al., 2009, and references cited therein). In the European Alps, however, research on rock glacier kinematics has mainly focused on seasonal, annual, and decennial scales, covering, at the earliest, the second half of the twentieth century (e.g. Delaloye et al., 2010, and references cited therein).
Little interest has so far been given to the mean- and long-term (century to millennia) kinematics of these landforms (e.g. André, 1994; Sloan and Dyke, 2004; Frauenfelder et al., 2005), due to the lack of suitable methods for a correct spatial definition of rock glacier movements on mean- to long-term temporal scales (e.g. Frauenfelder, 2005; Scapozza, 2013).

Such work is limited by the availability of vertical aerial photographs in the early decades of the twentieth century (e.g. Avian et al., 2005; Roer et al., 2005; Delaloye et al., 2010) as well as the difficulty of dating over the longer term (i.e. millennial timescales). Concerning the millennial-scale, the problem has in part been resolved with surface exposureage dating techniques such as the Terrestrial Cosmogenic Nuclides (TCNs) or Schmidt hammer exposure-age dating (SHD) (e.g. Winkler, 2009; Shakesby et al., 2011).

The main objective of this study is to analyse existing links between rock glacier kinematics and trends in mean air temperature on annual to centennial and millennial scales. For this purpose, we have used the case study of the Stabbio di Largario rock glacier in the southern Swiss Alps (Figure 1A) by combining three different methods for assessing the rock 

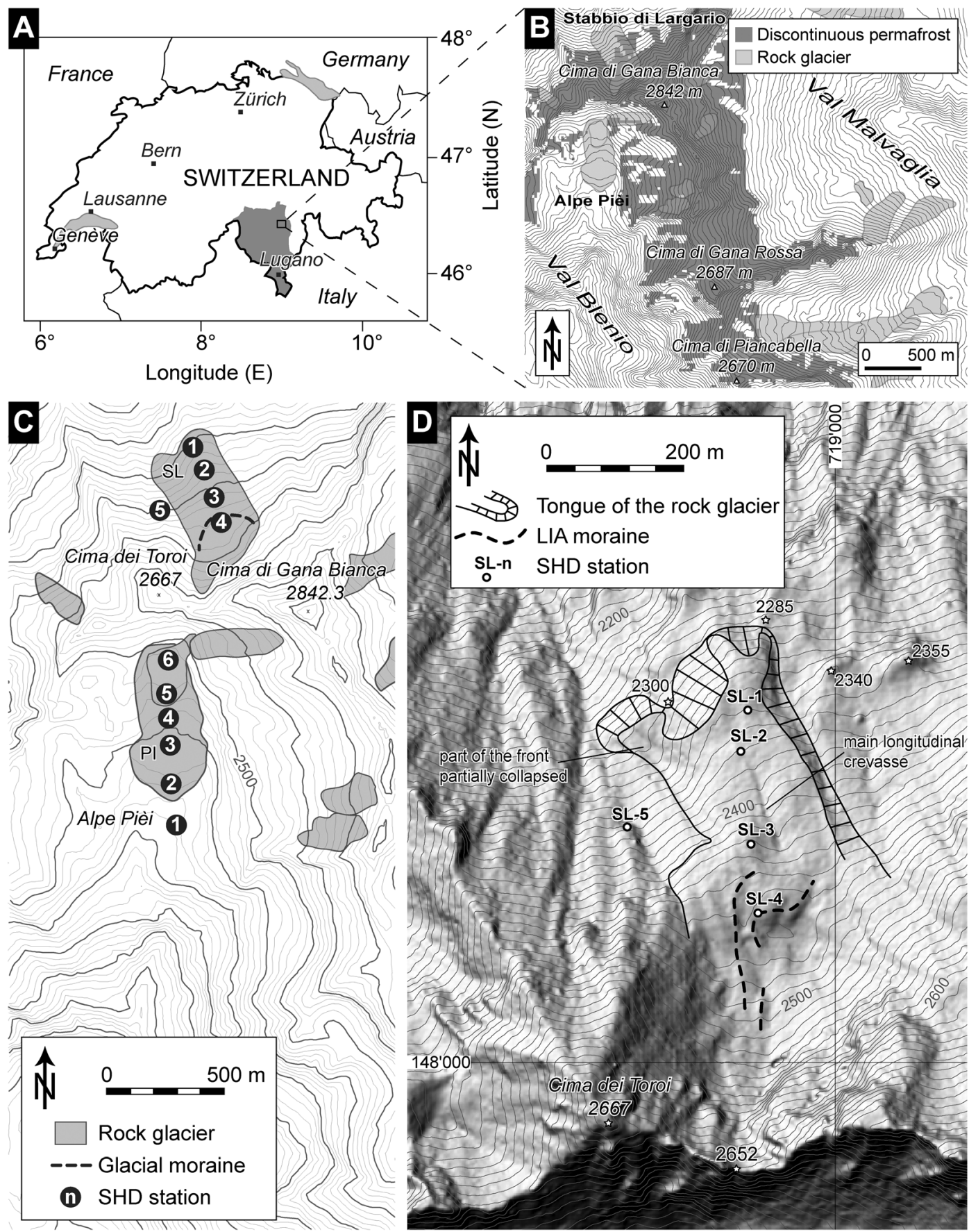

Figure 1. Geographical location of the studied rock glaciers. (A) Localization in Switzerland and in the Canton of Ticino (in grey). (B) Localization of the Cima di Gana Bianca massif and regional permafrost distribution from the empirical model developed by Scapozza and Fontana (2009). (C) Stabbio di Largario (SL) and Alpe Pièi (PI) rock glaciers and relative Schmidt hammer exposure-age dating (SHD) stations. (D) Detail about the morphology and the SHD stations on the Stabbio di Largario rock glacier (basemap source: Swiss Federal Office of Topography swisstopo). Coordinates are expressed in the Swiss grid CH1903 LV03.

glacier kinematics: the SHD for reconstructing the long-term kinematics (millennial scale); digital monophotogrammetry for calculating the horizontal surface movements on the centennial to decennial scale; and differential global positioning system (GPS) monitoring to provide information regarding short-term creeping variations (seasonal to annual scale). Particular emphasis will be given to the digital monophotogrammetry technique, which is applied here for the first time in studies of rock glacier kinematics.

\section{Study Area and Site Characteristics}

The study area is located on the orographic left side of the Soi Valley, in the northern part of the Cima di Gana Bianca massif (eastern Ticino Alps between the Blenio Valley and the Malvaglia Valley; Figure 1B) in the southern Swiss Alps.

The region is characterized by old polycyclic paragneiss and orthogneiss (Galster et al., 2012) and belongs to the Simano Nappe, which in turn is included in the Lower Penninic. The semi-continental climate is characterized by high temperatures in summer and two maxima in precipitation in spring and in autumn. At $2500 \mathrm{~m}$ above sea level (a.s.l.), the mean annual precipitation (MAP) is around $2270 \mathrm{~mm} / \mathrm{a}$, whereas the mean annual air temperature (MAAT) is around $-0.6^{\circ} \mathrm{C}$ (Scapozza and Fontana, 2009).

After the pioneer study of Zeller (1964), the peri-glacial geomorphology of the study area has been systematically analysed since 2005, with research on the description and the palaeoclimatic significance of existing rock glaciers (e.g. Scapozza 
et al., 2010; Scapozza, 2013) and their dynamics (e.g. Ramelli et al., 2011; Mari et al., 2011), on the local geophysical characterization of permafrost (e.g. Scapozza et al., 2011a), and on the modelling of the permafrost distribution on the regional scale (e.g. Scapozza and Fontana, 2009).

This study focuses on the Stabbio di Largario rock glacier (Figure 1C), which belongs to the Swiss permafrost monitoring network PERMOS (2010). It is a monomorphic (i.e. constituted by a single landform) rock glacier (sensu Frauenfelder and Kääb, 2000), situated between 2240 and $2600 \mathrm{~m}$ a.s.I. on the northern flank of the Cima dei Toroi (2667 m a.s.l.) and of the Cima di Gana Bianca (2842 m a.s.I.). The rock glacier presents evidence of possible incipient destabilization of the entire landform (cf. Ramelli et al., 2011), as indicated by a large longitudinal 3-4 $\mathrm{m}$ deep crevasse without visible ice and several long transversal crevasses in the central part, some tens of metres long, whereas the western part of the front has partially collapsed in the small stream situated in the northwestern part of the catchment (Figure 1D). Indeed, no signs of transversal crevasses are visible in vertical aerial photographs of the Stabbio di Largario before 2001 (not shown here). A topographic depression situated in the upper part of the rock glacier at $2470 \mathrm{~m}$ a.s.l. was occupied by a small glacier during the Little Ice Age (LIA) (Maisch, 1992), with perennial ice patches persisting until AD 2004 and several small moraines left in the upper part of the rock glacier (Figure 1D).

For calibration purposes, part of the investigations referring to the Schmidt hammer measurements were also carried out on the Alpe Pièi rock glacier, which is a large polymorphic (i.e. presenting two or more superimposed lobes that can present a different degree of activity) rock glacier (sensu Frauenfelder and Kääb, 2000), composed of two distinct superimposed lobes. This landform is located between 2340 and $2560 \mathrm{~m}$ a.s.l. on the southern flanks of the Cima dei Toroi and of the Cima di Gana Bianca (Figure 1C).

\section{Methods}

\section{Schmidt hammer exposure-age dating (SHD)}

The Schmidt hammer is a lightweight mechanical instrument allowing a rapid and non-destructive control of the quality of concrete based on the measurement of a rebound value (Schmidt, 1950). The a-dimensional rebound value ( $R$-value) is proportional to the compression resistance of the rock surface and to the weathering degree of the rock sample, when assuming the same lithology and climate conditions and lowers with increasing exposure times (McCarroll, 1989). The $R$-values allow dating of the exposure-age of the rock surface (i.e. a minimal age of the surface) when considering the transport-related surface roughness of the measured rock sample. In glacial, fluvio-glacial and fluvial environments blocks may be polished and rounded during transport above, within or below the glacier or as a function of the transport distance (McCarroll, 1989; Shakesby et al., 2006).

The Schmidt hammer has been used frequently since the 1980s (cf. Goudie, 2006) in chronostratigraphical studies in glacial and peri-glacial environments for the relative dating of the surface of moraines (Evans et al., 1999; Shakesby et al., 2006; Winkler, 2009), pronival ramparts (Matthews et al., 2011) and rock glaciers (Frauenfelder et al., 2005; Kellerer-Pirklbauer et al., 2008; Scapozza et al., 2011b). When $R$-values of two or more surfaces of known age are available, the Schmidt hammer exposure-ages may be calibrated using a linear regression as suggested by Kellerer-Pirklbauer (2008), Matthews and Owen (2010) and Shakesby et al. (2011) or a curvilinear relationship if the median $R$-values are a power law function of exposure age as suggested by Stahl et al. (2013).

In this study, we defined five measurement locations of five blocks each on which 10 points of measurement were performed using a LD type Schmidt hammer (Digi-Schmidt 2000 from Proceq). For each point, $R$-value measurement was repeated four times (four consecutive impacts), giving in total 200 measures per location (see Scapozza et al., 2011b, for details). In order to calculate the overall mean $R$-value for each measurement location, for every measurement point extreme values were discarded and the arithmetical mean between the remaining median values was first calculated. A standard measurement error in the $95 \%$ confidence interval was then calculated (Kellerer-Pirklbauer, 2008) to compare relative ages.

Age differences between two measurement locations were considered statistically significant when the $95 \%$ confidence intervals did not superimpose. Based on the results of Scapozza (2013), who found linear relationships between $R$-values of three surfaces of known age in two different lithologies of the Cima di Gana Bianca Massif, we used linear regression for calibrating the age data. The $95 \%$ confidence interval of $R$-values was then used to calculate the error of the calibrated exposure-age separately for each location (Shakesby et al., 2006; Kellerer-Pirklbauer, 2008).

Thanks to the SHD, it was possible to calculate long-term mean horizontal surface velocities of the Stabbio di Largario rock glacier as a function of the distance of the SHD location from the Rock Glacier Initiation Line Altitude (RILA). The RILA represents the altitude from which the rock glacier starts to creep out from the slope above (Humlum 1988, 2000). Similar to what André (1994) proposed for rock glaciers from Svalbard using exposure-age dating by lichenometry, the proposed approach consists of calculating the ratio between the difference in exposure-age and the horizontal distance of the two selected points. By doing so, we determine the mean surface velocity along a longitudinal velocity streamline of the rock glacier, which represents the opposite with respect to the age estimation of a rock glacier based on the photogrammetric quantification of streamlines form surface velocity fields (e.g. Avian et al., 2005; Kääb, 2005; Frauenfelder, 2005).

Dating of the glacial landforms (moraines, roches moutonnées, etc.) used for the exposure-age calibration are taken from Scapozza and Fontana (2009) and Scapozza (2013).

\section{Monophotogrammetry}

Monophotogrammetry (or monoplotting) involves obtaining measurements following georeferentiation of a single oblique unrectified photograph using a Digital Terrain Model (DTM) (Bozzini et al., 2012). In practical terms, each pixel of the photograph is linked to the corresponding pixel on the DTM so that it can be referred to in the correspondent real world coordinates (i.e. georeferenced coordinates). The availability of high resolution DTMs is of primary importance for applying this technique. Contrary to classical stereophotogrammetry, where the three-dimensional (3D) position of every pixel can be determined by overlapping a stereopair of photographs, in monophotogrammetry the correct location of a pixel can be only obtained by a precise correlation of the photographs with the DTM.

The WSL-Monoplotting-tool (Bozzini et al., 2012; Conedera et al., 2013) we used in this study was designed to orthorectify the visible landscape on oblique single pictures and to produce and export georeferenced vector data by drawing them directly on the analysed photographs. The tool enables orthorectification of the digital image to the DTM by defining at least four control points clearly and precisely identifiable both on the photograph 
and in georeferenced and orthorectified maps (topographical maps, orthophotos, cadastral surveys, etc.). The quality of georeferentiation of the photographs is dependent on the accuracy of definition of the control points, which must be unambiguous (e.g. roads, footpath intersections, buildings, rocky outcrops, wall corners, etc.), homogeneously distributed across the photograph and possibly placed on the ground surface (thus on the DTM) (Bozzini et al., 2012).

The camera calibration consists of an iterative approach aimed at finding the camera parameters that minimize the error between the defined and the calculated 3D position of the control points. The quality of the camera calibration is finally assessed by verifying the georeferentiation precision of the defined control points both in quantitative [two-dimensional (2D) and 3D metric error on the georeferenced oblique photographs] and qualitative (position of the mapped elements, projection of georeferenced elements on the oblique photograph) terms (Figure 2).

In the presence of high quality photographs (e.g. high resolution, undistorted, etc.), high resolution DTMs (e.g. resolution $2 \mathrm{~m}$, no modification of the topography since the time of the picture) and accurately defined control points (e.g. number and distribution on the photograph), it is possible to achieve precision levels better than $1 \mathrm{~m}$ and between 0.5 and $5 \mathrm{~m}$ on average (Conedera et al., 2013). For the present study, we searched in local archives and in Solari (1998) finding six useful historical photographs representing the Stabbio di Largario rock glacier between AD 1910 and 2010. Because of the generally large incidence angle of the available photographs with respect of the DTM of the rock glacier, we cannot exclude large location errors when georeferencing morphological elements in the picture. In order to crosscheck the theoretical georeferencing error, four rocky outcrops corresponding to the four elevation points 2285, 2300, 2340 and $2355 \mathrm{~m}$ a.s.I. in Figure 1D, assumed to be stable with time, but not considered as control points for calibrating the pictures, were additionally recognized and mapped in every photograph.

\section{Differential global positioning system (dGPS)}

The differential global positioning system (dGPS) allows measurement of the 3D position of a site on the earth with an accuracy of some centimetres (Little et al., 2003). It is based on the simultaneous utilization of two antennas: a fixed reference antenna and a rover antenna for field data acquisition. Placing the reference antenna at a point of known coordinates allows a real-time correction of the measured coordinates thanks to the rover antenna (Lambiel and Delaloye, 2004). The rover antenna is connected with the reference antenna by a radio signal, allowing the measurement of the position of survey points with an accuracy of 1 to $3 \mathrm{~cm}$. On the Stabbio di Largario rock glacier, 33 points distributed over the entire surface of the landform were measured every year since AD 2009 by placing the reference antenna at the same point. The displacements were then converted in horizontal surface velocities (in $\mathrm{cm} / \mathrm{a}$ ). Two control points placed on fixed points (bedrock surface) allowed an assessment of the data quality attribute for every measurement. In this study, dGPS measurements were carried out with SR 530 equipment by Leica Geosystems. In total, five dGPS data acquisition campaigns were organized between 2009 and 2012. Two measurements for the definition of the summer velocities were taken in July and October 2009, respectively, whereas an additional three measurement campaigns were conducted in 2010, 2011 and 2012 around the end/beginning of the hydrological year, which is 30 September1 October in Switzerland. The measured velocities were also put in relation with the displacements obtained through analysis of

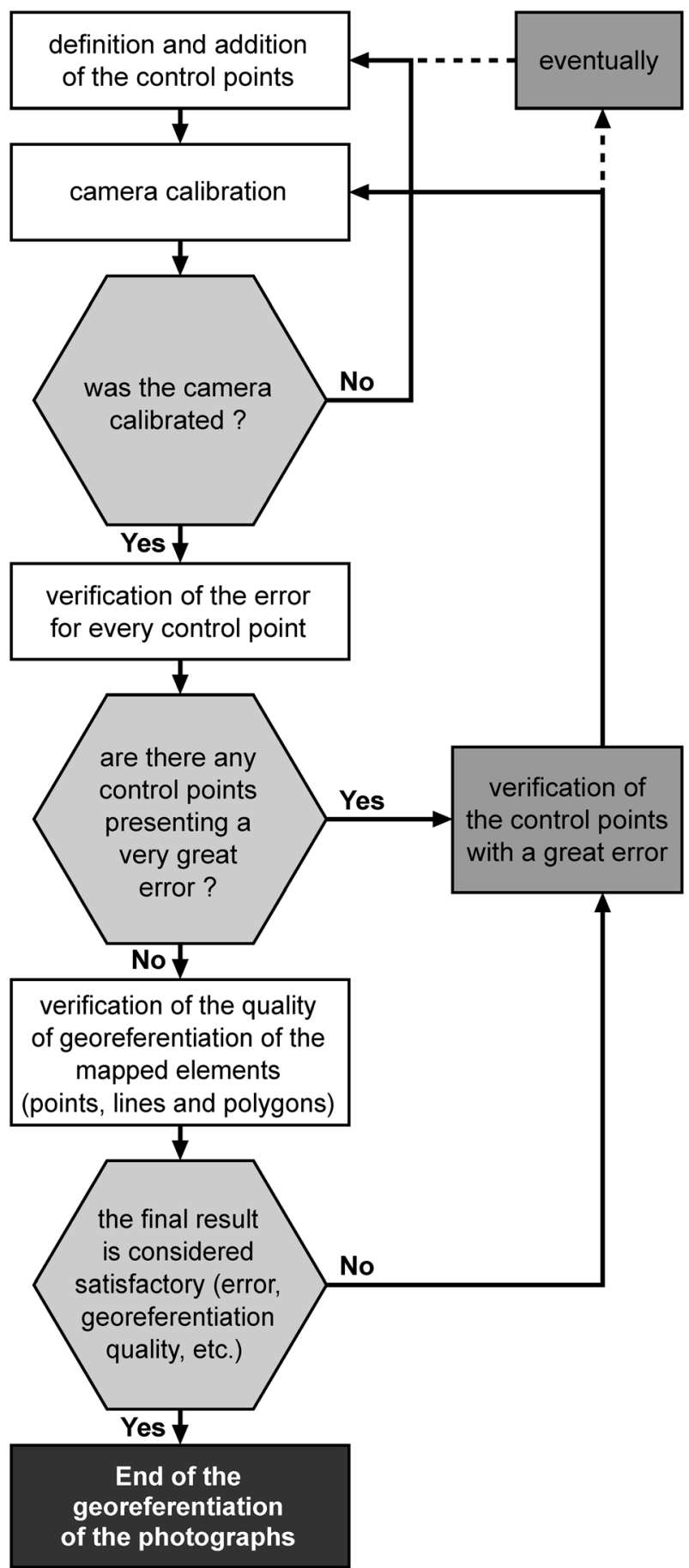

Figure 2. Iterative procedure for georeferencing oblique non-metric photographs with the WSL-Monoplotting-tool. The procedure is based on a quantitative (2D and 3D metric error on the georeferenced oblique photographs) and qualitative (position of the mapped elements, projection of georeferenced elements on the oblique photograph, etc.) assessment of the georeferentiation error and on a repetition of the fundamental operations of definition (and, eventually, re-definition) of the control points and of calibration of the camera.

InSAR (space-borne Synthetic Aperture Radar Interferometry; e.g. Strozzi et al., 2004; Lambiel et al., 2008) images for the period 1994-2007 (Mari et al., 2011).

\section{Results}

\section{Schmidt hammer exposure-age dating (SHD)}

Mean Schmidt hammer $R$-values measured on five locations of the Stabbio di Largario rock glacier (Figures 1D and 3A, Table I) 
range from 48 on the Younger Dryas surface located close to the rock glacier (SL-5) to 60 in the rooting zone of the landform (SL-4), which was occupied by a small glacier during the LIA. The $R$-values increase linearly with the altitude from the front towards the rooting zone of the rock glacier (Figure 3A), indicating an increase in exposure-ages towards the front. The differences in $R$-values are significant between the lower part (SL-1-2) and the upper part (SL-3-4) of the rock glacier and between the whole rock glacier and SL-5 $(p<0.05)$.

For Alpe Pièi (Figures $1 \mathrm{C}$ and $3 \mathrm{~A}$, Table I), mean $R$-values range from 44 on roches moutonnées of the Oldest Dryas located downhill on the rock glacier front (PI-1) to 57 on the upper part of the landform (PI-4-6). The exposure-age differences between the roches moutonnées and the rock glacier, and between the two lobes of the rock glacier (with the exception of the location PI-4), are significant $(p<0.05)$, allowing a consideration of the exposure-age of both rather homogeneous lobes and the lower lobe, which is older than the upper one (Figure 3A). Due to their position on the upper part of the lower lobe, it is very probable that blocks of location PI-4 fell from the top of the front of the upper lobe. This would explain the same $R$-value for location PI-4 and PI-5. Finally, no significant differences in $R$-values were detected between the two rock glaciers. However, this is not the case for the two Lateglacial surfaces of glacial erosion, where the Younger Dryas surface (SL-5) is significantly younger than the Oldest Dryas roches moutonnées $(\mathrm{PI}-1)$.
The calibration of SHD for the two rock glaciers (composed of the same lithology) was performed thanks to the AD 1850 glacial moraine (location SL-4) present at the rooting zone of the Stabbio di Largario rock glacier (Figure 1D) and to the two glacial erosion surfaces attributed to the end of the Younger Dryas (SL-5) and to the Oldest Dryas (PI-1) (Figure 3B). For the Stabbio di Largario rock glacier, Schmidt hammer exposureages (i.e. minimal ages of the rock glacier surface) are between $3.9 \pm 0.7 \mathrm{ka}$ cal BP just above the front (SL-1) and $1.1 \pm 0.9 \mathrm{ka}$ cal BP downhill of the LIA moraine (SL-3) (Table II). For the Alpe Pièi rock glacier, a difference of about two millennia is present in the Schmidt hammer exposure-ages between the lower lobe (5.8-3.8 ka cal BP; range of the SHD PI-2 and Pl-3) and the upper lobe (3.8-2.2 ka cal BP; range of the SHD PI-5 and PI-6).

Long-term mean horizontal surface velocities calculated through use of the SHD and considering the mean age of each SHD are presented in Figure 3C. The age error based on the 95\% confidence interval was used for calculating a mean velocity error of $0.75 \mathrm{~cm} / \mathrm{a}$. The horizontal surface velocities (Table III) calculated on the basis of the SHD range between 6.0 and $7.5 \mathrm{~cm} / \mathrm{a}$ from $3.0 \mathrm{ka} \mathrm{cal} \mathrm{BP}$ and present an increase (from 6.4-7.9 to 9.3-10.8 cm/a) from $1.1 \mathrm{ka}$ cal BP. Considering the position of the SHD locations, it is possible to exclude the influence of slope angle on the calculated mean horizontal surface velocities. Their increase from $1.1 \mathrm{ka}$ cal BP is in fact shown by SHD SL-3 and SL-4, which were placed in the rooting zone of the rock glacier where the slope angle is regular
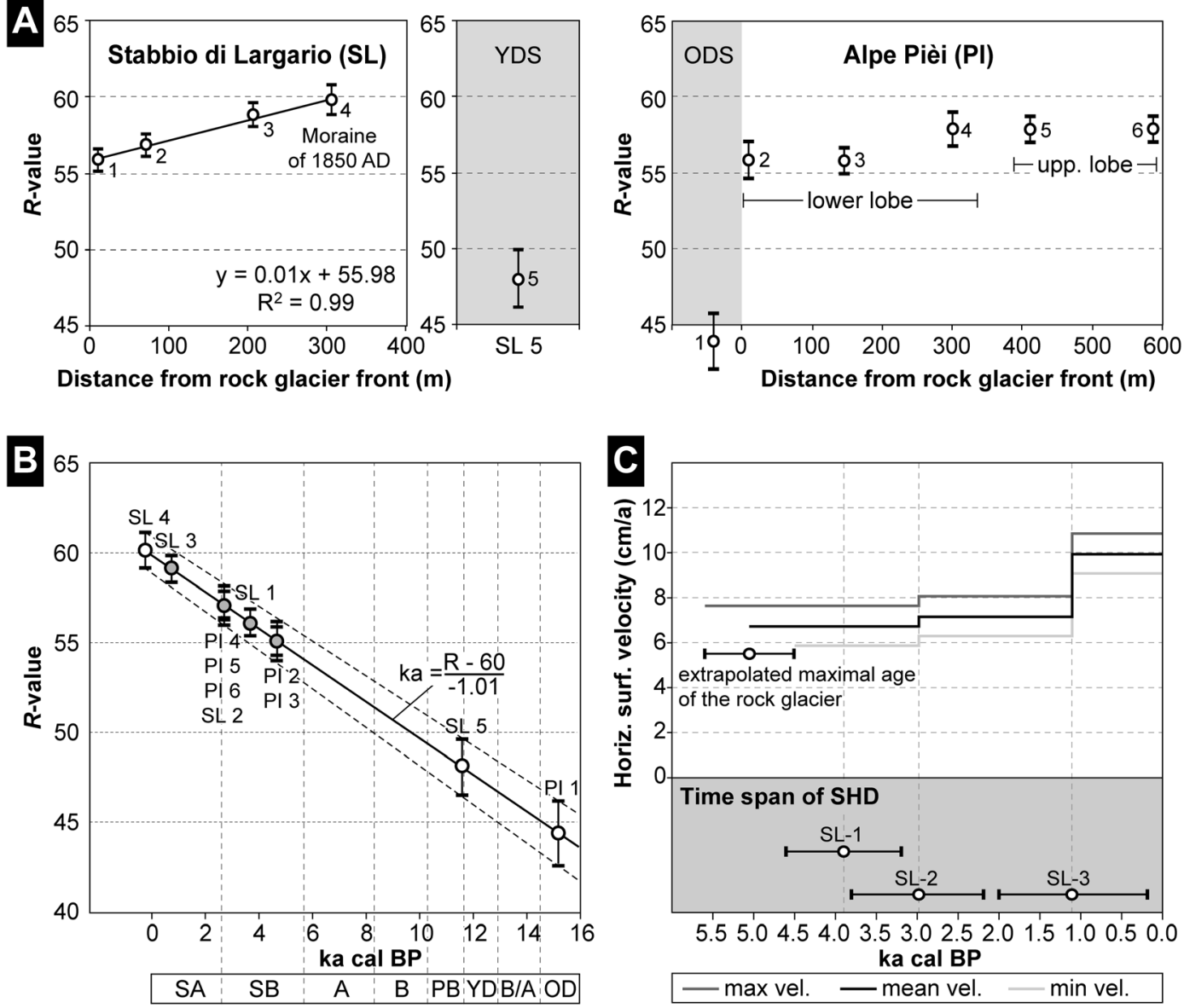

Figure 3. Schmidt hammer exposure-age dating (SHD) on the Stabbio di Largario rock glacier. (A) $R$-Values measured on the Stabbio di Largario and Alpe Pièi rock glaciers. In grey, non-rock glacier surfaces: YDS = Younger Dryas Surface; ODS = Oldest Dryas surface. (B) Calibration of SHD by linear regression (grey dots) in function of $R$-values measured on surfaces of known age (white dots) for the Stabbio di Largario (SL) and Alpe Pièi (PI) rock glaciers. Late-glacial and Holocene chronozones: $\mathrm{OD}=$ Oldest Dryas; $\mathrm{B} / \mathrm{A}=\mathrm{B} ø$ lling/Allerød; $\mathrm{YD}=$ Younger Dryas; $\mathrm{PB}=\mathrm{Preboreal}$; $\mathrm{B}=\mathrm{Boreal} ; \mathrm{A}=\mathrm{At}-$ lantic; $\mathrm{SB}=$ Subboreal; $\mathrm{SA}=$ Subatlantic. (C) Mean horizontal long-term displacement rates calculated in function of the SHD and of the distance from the rock glacier initiation line altitude (RILA). 
Table I. Schmidt hammer measurements

\begin{tabular}{|c|c|c|c|c|c|c|c|c|}
\hline \multicolumn{2}{|c|}{ Study site } & \multicolumn{3}{|c|}{ Coordinates } & \multicolumn{3}{|c|}{$R$-Value } & \multirow[b]{2}{*}{ Landform } \\
\hline Site & Location & $X$ & $Y$ & Altitude (m) & Mean & Standard deviation & $95 \%$ confidence interval & \\
\hline \multirow[t]{4}{*}{ SL } & 1 & 718875 & 148515 & 2350 & 56 & 3 & \pm 0.75 & Stabbio di Largario rock glacier \\
\hline & 2 & 718865 & 148455 & 2370 & 57 & 3 & \pm 0.77 & \\
\hline & 3 & 718880 & 148320 & 2430 & 59 & 3 & \pm 0.79 & \\
\hline & 4 & 718890 & 148220 & 2470 & 60 & 4 & \pm 1.00 & Moraine of $A D 1850$ \\
\hline \multirow[t]{6}{*}{ PI } & 1 & 718695 & 147020 & 2335 & 44 & 5 & \pm 1.76 & Oldest Dryas Surface \\
\hline & 2 & 718725 & 147125 & 2375 & 55 & 4 & \pm 1.07 & Alpe Pièi rock glacier, lower lobe \\
\hline & 3 & 718715 & 147260 & 2390 & 55 & 3 & \pm 0.80 & \\
\hline & 4 & 718695 & 147415 & 2420 & 57 & 4 & \pm 1.09 & \\
\hline & 5 & 718700 & 147525 & 2460 & 57 & 3 & \pm 0.79 & Alpe Pièi rock glacier, upper lobe \\
\hline & 6 & 718700 & 147700 & 2485 & 57 & 3 & \pm 0.79 & \\
\hline
\end{tabular}

Note: Geographical position (Swiss grid CH1903 LV03) of the locations where Schmidt hammer exposure-age dating (SHD) was performed, and rebound values measured on the Stabbio di Largario (SL) and Alpe Pièi (PI) rock glaciers. Italic typeface represents measurements used for the age-calibration.

Table II. Schmidt hammer exposure-age dating (SHD)

\begin{tabular}{|c|c|c|c|c|c|c|}
\hline \multicolumn{2}{|c|}{ Study site } & \multicolumn{2}{|r|}{$R$-Value } & \multicolumn{3}{|c|}{ Chronology } \\
\hline Site & Location & Mean & $95 \%$ confidence interval & Attributed age (ka cal вP) & Calculated age (ka cal BP) & Age error $( \pm k a)$ \\
\hline SL & 4 & 60 & \pm 1.00 & 0.1 & 0.2 & 0.9 \\
\hline SL & 3 & 59 & \pm 0.79 & - & 1.1 & 0.9 \\
\hline $\mathrm{Pl}$ & 4 & 57 & \pm 1.09 & - & 3.0 & 1.1 \\
\hline PI & 5 & 57 & \pm 0.79 & - & 3.0 & 0.8 \\
\hline PI & 6 & 57 & \pm 0.79 & - & 3.0 & 0.8 \\
\hline SL & 2 & 57 & \pm 0.77 & & 3.0 & 0.8 \\
\hline SL & 1 & 56 & \pm 0.75 & - & 3.9 & 0.7 \\
\hline PI & 2 & 55 & \pm 1.07 & - & 4.8 & 1.0 \\
\hline $\mathrm{PI}$ & 3 & 55 & \pm 0.80 & - & 4.8 & 0.7 \\
\hline SL & 5 & 48 & \pm 1.86 & 12.0 & 11.3 & 1.4 \\
\hline PI & 1 & 45 & \pm 1.76 & 14.5 & 15.0 & 1.1 \\
\hline
\end{tabular}

Note: Calibration by linear regression of the rebound values measured on the Stabbio di Largario (SL) and Alpe Pièi (PI) rock glaciers. The age was obtained by the age-calibration of the mean $R$-value, whereas the age error was calculated by and age-calibration of the $95 \%$ confidence interval (see text for details).

Table III. Mean horizontal surface velocities of the Stabbio di Largario rock glacier derived from the Schmidt hammer exposure-age dating (SHD)

\begin{tabular}{|c|c|c|c|c|c|c|c|c|c|}
\hline \multicolumn{3}{|c|}{ SHD } & \multicolumn{3}{|c|}{ Period of time (ka) } & \multirow{2}{*}{$\begin{array}{l}\text { Horizontal } \\
\text { distance } \\
(\mathrm{m})\end{array}$} & \multicolumn{3}{|c|}{ Horizontal velocity $(\mathrm{cm} / \mathrm{a})$} \\
\hline No. & Age (ka cal вP) & Age error $( \pm k a)$ & Long time & Mean time & Short time & & Maximum & Mean & Minimum \\
\hline SL-1 & 3.90 & 0.70 & 1.02 & 1.15 & 1.28 & - & - & - & - \\
\hline SL-2 & 3.00 & 0.80 & 0.80 & 0.90 & 1.00 & 61 & 7.5 & 6.8 & 6.0 \\
\hline SL-3 & 1.10 & 0.90 & 1.80 & 1.90 & 2.00 & 136 & 7.9 & 7.2 & 6.4 \\
\hline SL-4 & 0.10 & - & 1.90 & 1.00 & 0.10 & 100 & 10.8 & 10.0 & 9.3 \\
\hline
\end{tabular}

Note: The age error was used for calculating the range of velocity of the Stabbio di Largario rock glacier (see also Figure 3C).

(constant distance between the contour lines on Figure 1D), and not by the SHD performed on the rock glacier tongue, where the slope is steeper.

\section{Monophotogrammetry}

All six selected photographs (Figure 4) were georeferenced with a submetric mean theoretical 3D error and a maximal 3D error ranging from 69 to $397 \mathrm{~cm}$ (Table IV).

A major problem in mapping morphological elements of the rock glacier through monoplotting is created by the DTM. Indeed, the application of the actual DTM (SwissALTI3D of the Swiss Federal Office of Topography swisstopo) causes a significant error in the georeferentiation of the mapped elements, because the advancing rock glacier buries the earlier positions of the rock glacier front. To overcome this problem, a smoothed DTM of the rock glacier surface was created by interpolating the contour lines within the rock glacier perimeter (Figure 5A). The smoothed DTM allowed a realistic mapping of the front edge for almost all photographs (Figure 5B). Concerning the photograph SOL138 (Figure 4A), the incidence angle was too large and the mapped points were projected 'behind' the real topography and thus not intercepted by the smoothed DTM. In this case, a less precisely definable morphological element such as the front base was mapped. 

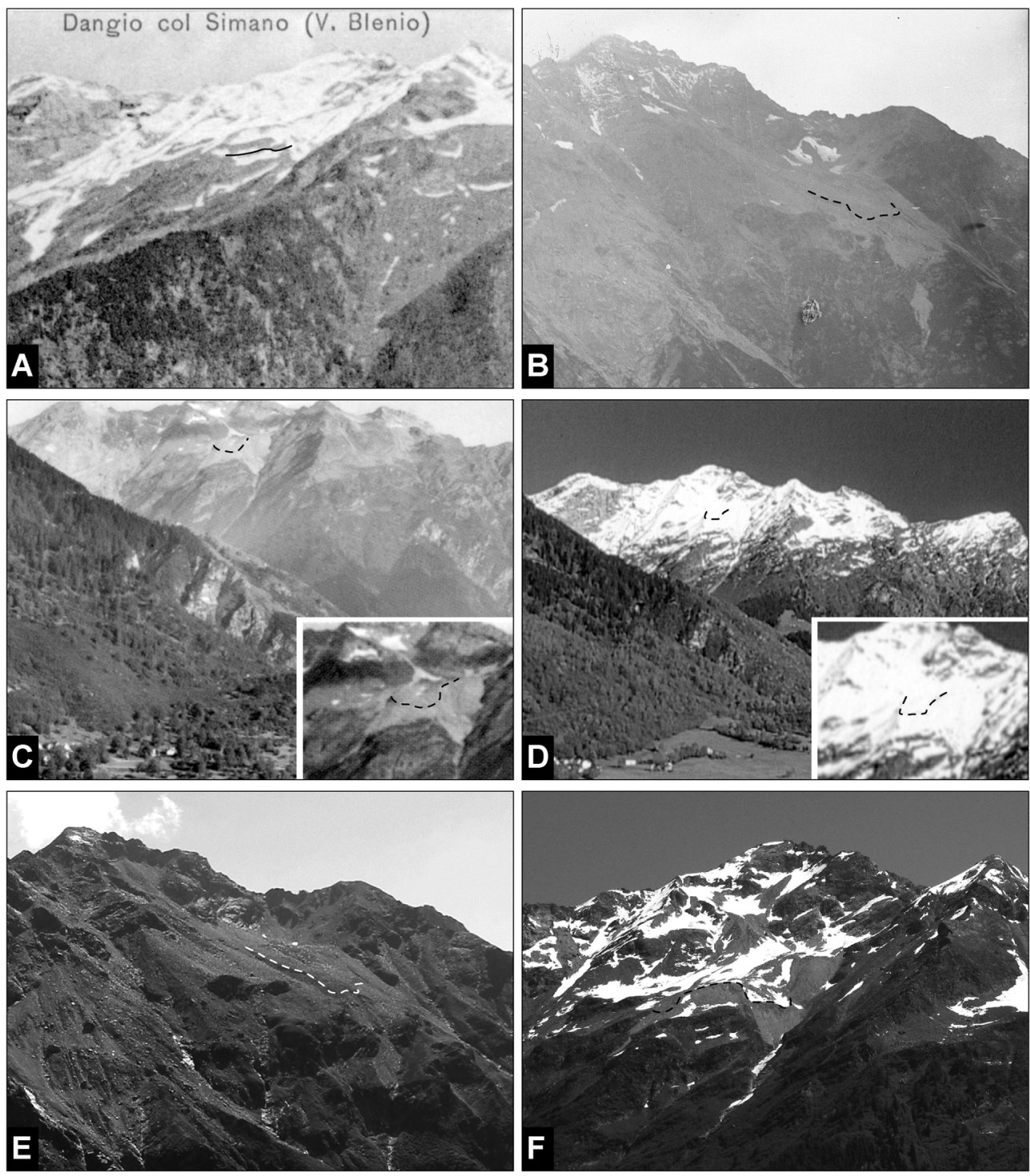

Figure 4. The Stabbio di Largario rock glacier on the six oblique terrestrial photographs analysed thanks to the WSL-Monoplotting-tool (detail of the photograph). (A) SOL138, taken from a postcard of 1910. Reproduced with the permission of Luca Solari. (B) DON2894, taken by Roberto Donetta in 1924. Reproduced with the permission of the 'Fondazione Archivio Fotografico Roberto Donetta', Corzoneso. (C) SOL148, taken by Willi Borelli in 1940. Reproduced with the permission of Luca Solari and of the 'Archivio Borelli', Airolo. (D) SOL149, taken by Luca Solari in 1996. Reproduced with the permission of Luca Solari. (E) SCA30082008, taken by Cristian Scapozza on 30 August 2008. (F) SCA27062010, taken by Cristian Scapozza on 27 July 2010. On the photographs, the elements allowing the reconstruction of the position of the rock glacier are reported: dashed lines correspond to the edge of the front, whereas the solid line in photograph SOL138 corresponds to the base of the front.

Table IV. Terrestrial photographs analysed with the WSL-Monoplotting-tool.

\begin{tabular}{|c|c|c|c|c|c|c|}
\hline \multirow[b]{2}{*}{ Photograph } & \multirow[b]{2}{*}{ Date } & \multirow[b]{2}{*}{ Resolution } & \multirow[b]{2}{*}{ Control points } & \multicolumn{3}{|c|}{$3 \mathrm{D}$ error in real distance $(\mathrm{cm})$} \\
\hline & & & & Minimum & Maximum & Mean \\
\hline SOL138 & 1910 & Medium & 7 & 14 & 199 & 89 \\
\hline DON2894 & 1924 & High & 9 & 4 & 260 & 94 \\
\hline SOL148 & 1940 & High & 8 & 17 & 397 & 89 \\
\hline SOL149 & 1996 & High & 8 & 2 & 134 & 62 \\
\hline SCA30082008 & 30 August 2008 & High & 7 & 3 & 69 & 22 \\
\hline SCA27062010 & 27 June 2010 & High & 8 & 8 & 230 & 72 \\
\hline
\end{tabular}

Note: The maximal three-dimensional (3D) error of georeferentiation was used for calculating the range of velocity of the Stabbio di Largario rock glacier (see also Table $V$ and Figure 6A).

Finally, the horizontal distance between the defined rock glacier positions on the photographs and the related horizontal surface velocity variations of the front of the rock glacier since AD 1910 were calculated (Table $V$ and Figure 6A) from the mapped morphological elements (Figures 4 and 5B), also considering the errors generated by the line of sight angle (error of orthorectification due to zones of the rock glacier not represented in the photographs) and the georeferentiation error. Horizontal surface velocities were calculated along a longitudinal streamline relating the rooting zone to the frontal part of the 

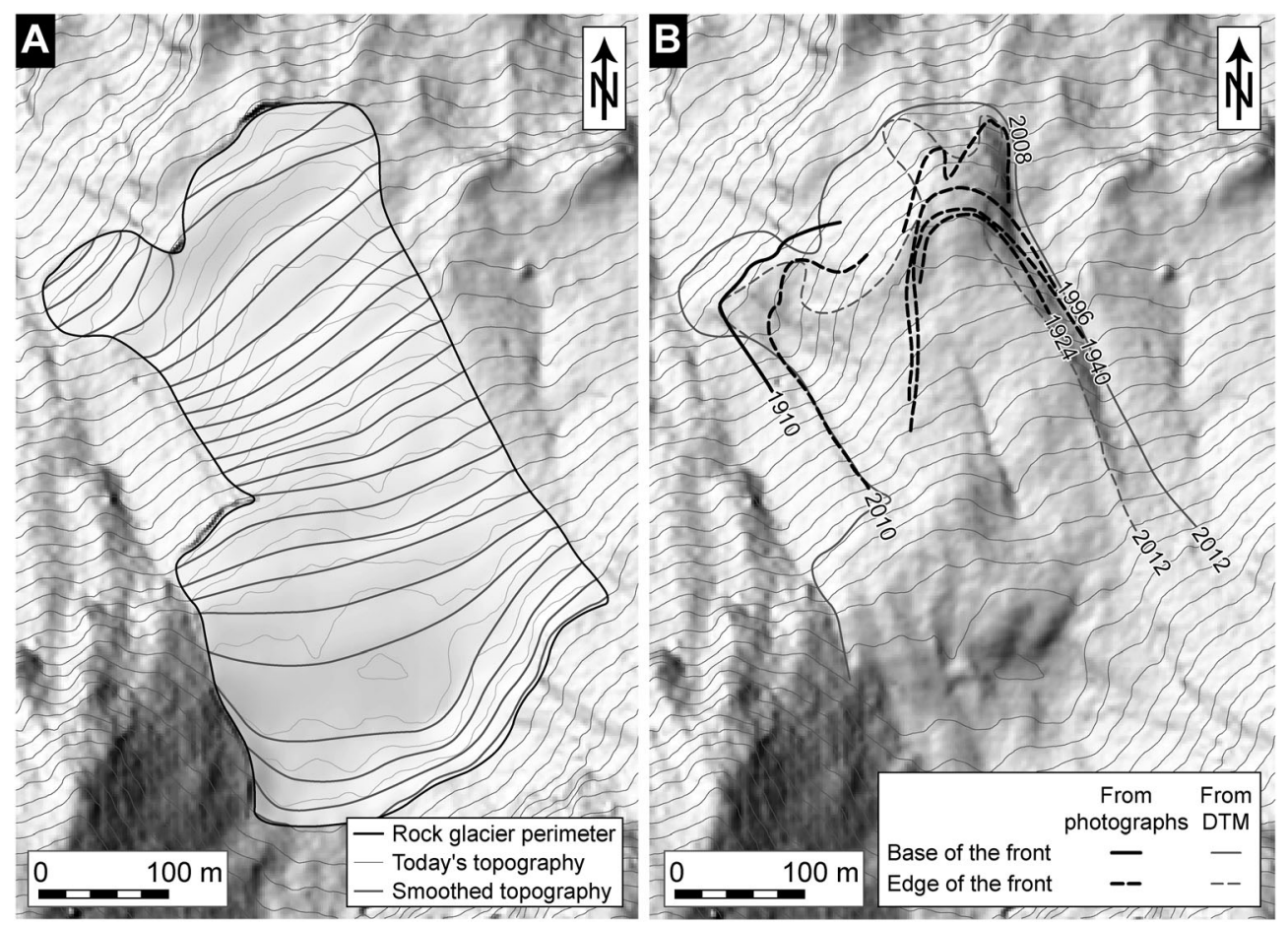

Figure 5. Topographical model of the base of the rock glacier and former positions of the front. (A) Hillshade of the modelled topography of the base of the rock glacier reconstructed thanks to a smoothed model of contour lines. (B) Orthorectified projection of the elements allowing the reconstruction of the position of the rock glacier defined in Figure 4 (basemap source: Swiss Federal Office of Topography swisstopo).

Table V. Mean horizontal surface velocities of the Stabbio di Largario rock glacier as derived by the monophotogrammetry (see also Figure 6A).

\begin{tabular}{|c|c|c|c|c|c|c|c|c|c|c|}
\hline \multirow[b]{2}{*}{ Photograph } & \multirow{2}{*}{$\begin{array}{l}\text { Year } \\
\text { (AD) }\end{array}$} & \multirow{2}{*}{$\begin{array}{l}\text { Maximum } \\
\text { georeferentiation } \\
\text { error }(\mathrm{cm})\end{array}$} & \multirow[b]{2}{*}{ Period (AD) } & \multicolumn{3}{|c|}{ Horizontal distance up to next position $(\mathrm{cm})$} & \multirow{2}{*}{$\begin{array}{c}\text { Time } \\
\text { (a) }\end{array}$} & \multicolumn{3}{|c|}{ Horizontal surface velocity $(\mathrm{cm} / \mathrm{a})$} \\
\hline & & & & Minimum & Mean & Maximum & & Minimum & Mean & Maximum \\
\hline Orthophoto & 2012 & - & & - & - & - & - & - & - & - \\
\hline SCA27062010 & 2010 & 230 & 2010-2012 & 0 & 180 & 410 & 2 & 0.00 & 90.00 & 205.00 \\
\hline SCA30082008 & 2008 & 69 & 2008-2010 & 181 & 250 & 319 & 2 & 90.50 & 125.00 & 159.50 \\
\hline SOL149 & 1996 & 134 & 1996-2008 & 736 & 870 & 1004 & 12 & 61.33 & 72.50 & 83.67 \\
\hline SOL148 & 1940 & 397 & 1940-1996 & 1223 & 1620 & 2017 & 56 & 21.84 & 28.93 & 36.02 \\
\hline DON2894 & 1924 & 260 & 1924-1940 & 160 & 420 & 680 & 16 & 10.00 & 26.25 & 42.50 \\
\hline SOL138 & 1910 & 199 & 1910-1924 & 51 & 250 & 449 & 14 & 3.64 & 17.86 & 32.07 \\
\hline SOL138 & 1910 & 199 & 1910-2012 & 3391 & 3590 & 3789 & 102 & 33.25 & 35.20 & 37.15 \\
\hline
\end{tabular}

Note: Data for photograph SOL138 reported in italic typeface were calculated on the basis of the time difference from the position determined for 1924 on photograph DON2894 thanks to the horizontal surface velocities calculated for the period 1910-2012 (and determined from the difference of position of the base of the front).

rock glacier. It is clear that this approach does not allow a calculation of horizontal surface velocities sensu strictu, because the front advance is not equivalent to surface velocities. Mean velocities of the Stabbio di Largario rock glacier presented here in fact refer only to its frontal part, because they were calculated on the basis of the difference in the position of the front of the rock glacier.

Calculated mean velocities range from c. $18 \mathrm{~cm} / \mathrm{a}$ for the period AD 1910-1924 to values higher than $70 \mathrm{~cm} / \mathrm{a}$ after AD 1996, whereas values for 2008 and 2010 are probably overestimated because of the short period of time between the defined positions.

\section{Differential global positioning system (dGPS)}

Horizontal surface velocities for the present day were derived from dGPS and ranged from 24 to $35 \mathrm{~cm} / \mathrm{a}$ in the middle of the rock glacier and from 49 to $56 \mathrm{~cm} / \mathrm{a}$ in the front part of the rock glacier (Figure 6B). Velocities of the middle increased from 2009 to 2012, whereas at the front, maximum velocities were obtained during the hydrological year 2011. The mean horizontal surface velocity of the entire rock glacier ranges from 34 (summer 2009) to $39 \mathrm{~cm} / \mathrm{a}$ (hydrological year 2011). The mean value for the whole measurement period (10 July 2009-18 September 2012) is $53 \mathrm{~cm} / \mathrm{a}$ in the front part (mean of 12 dGPS points), $30 \mathrm{~cm} / \mathrm{a}$ in the middle part (mean of seven dGPS points), and $36 \mathrm{~cm} / \mathrm{a}$ for the entire rock glacier (mean of 25 points measured on the rock glacier surface between the front and the rooting zone).

\section{Discussion}

Age of development of the rock glacier

Velocity curves derived from the three different methods applied are easily consolidated into a consistent overall picture. Long-term SHD mean velocity is quite slow $(10.0 \pm 0.8 \mathrm{~cm} / \mathrm{a})$ but in the same order of magnitude of the mean value of 

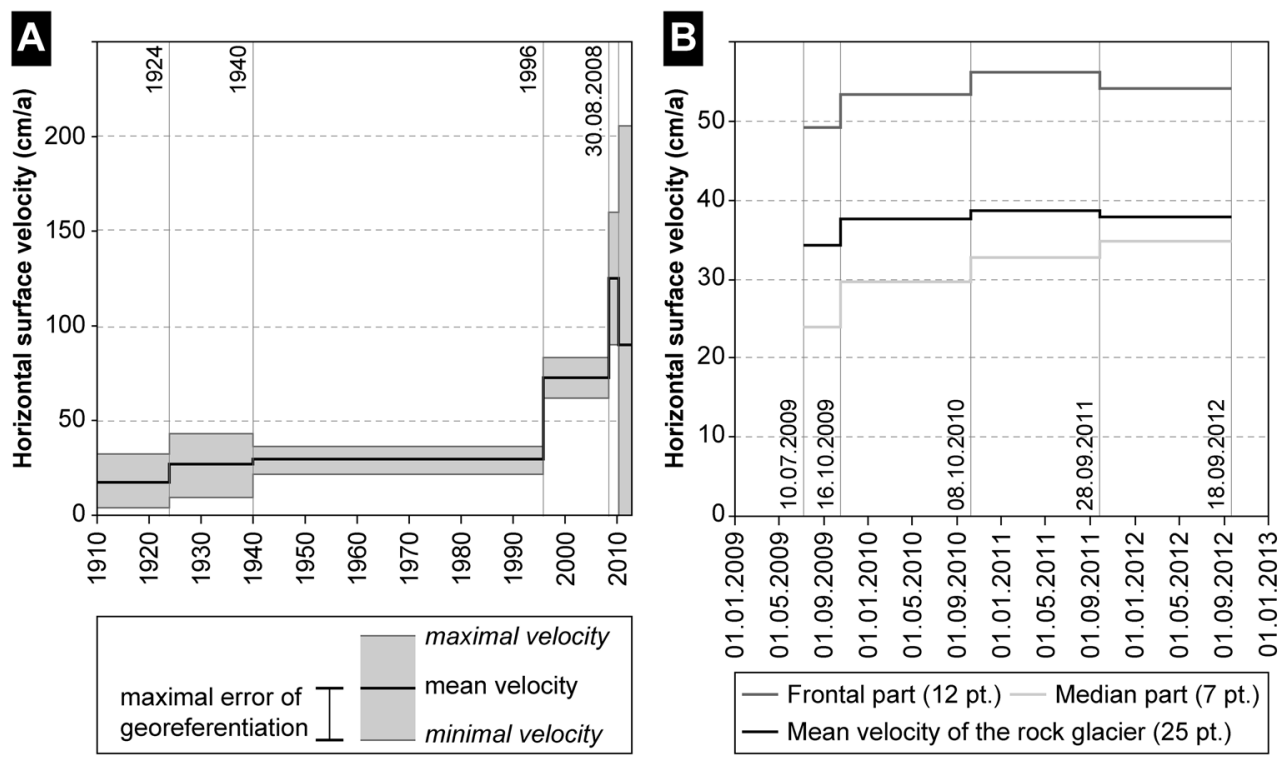

Figure 6. Horizontal surface velocities of the Stabbio di Largario rock glacier. (A) Values calculated thanks to the WSL-Monoplotting-tool (see also Table V). (B) Values calculated on the basis of dGPS monitoring of a network of 25 selected blocks distributed on the surface of the rock glacier.

$17.9 \pm 14.2 \mathrm{~cm} / \mathrm{a}$ resulting from the WSL-Monoplotting-tool analysis for the beginning of the twentieth century. Similarly, the high monophotogrammetry-derived velocities since the 1990s $(72.5 \pm 11.2 \mathrm{~cm} / \mathrm{a})$ are in the same order of magnitude as the maximal dGPS velocities range $(49.1-56.1 \mathrm{~cm} / \mathrm{a})$. It is in fact not surprising that the monophotogrammetry-derived velocities based on the front position, which is the fastest part of the Largario rock glacier, are higher when compared with horizontal surface velocities of the entire front part as assessed with annual dGPS monitoring. Nevertheless, the advance rates of the rock glacier, derived from the changes in position of the front, do not exactly correspond with horizontal surface velocities, derived from the dGPS monitoring of the position of several boulders. Therefore, the apparent deceleration related to the transition from monophotogrammetry-derived velocities (Figure 6A) to the dGPS-derived velocities between 2008 and 2009 cannot be interpreted in terms of rock glacier kinematics.

Reliable synthesis of mean horizontal surface velocity curves of the Stabbio di Largario rock glacier over the last 6.0 ka (Figure 7A) and for the period between the end of the LIA (AD 1850) and today (Figure 8A) was possible. For the correct interpretation of synthesis velocity curves, however, it is important to consider the different errors of every method applied here. In particular, changes in the rock glacier kinematics along the twentieth century were derived exclusively from monophotogrammetry because it is very difficult to connect the advance rates of the front with the surface velocities (see earlier).

Long-term mean horizontal surface velocities along a longitudinal velocity streamline linking the rooting zone to the frontal part of the rock glacier, calculated on the basis of SHD measurements, enabled us to extrapolate the exposure-age of the rock glacier front at $5.05 \pm 0.57 \mathrm{ka} \mathrm{cal} \mathrm{BP}$. This is assumed to be the maximal exposure-age or surface age of the whole landform (i.e. the minimal age of development of the rock glacier) (Figure 3C). The 'real' age of the entire landform could be several centuries or millennia older than the surface age as determined by SHD, confirming that this rock glacier started to evolve during or just after the end of the Mid-Holocene climate optimum, which in Central Europe lies between $c$. 8.5-5.5 ka ВР $(\approx 9.5-6.3 \mathrm{ka} \mathrm{cal} \mathrm{BP})$ and was characterized by mean July temperatures $0.5-1.5^{\circ} \mathrm{C}$ higher than in the twentieth century (Burga et al., 2001). This result confirms other numerical (radiocarbon and TCNs) and SHD dating (see a compilation in Scapozza, 2013) of the development of active rock glaciers in the European Alps (e.g. Calderoni et al., 1993; Dramis et al., 2003; Frauenfelder et al., 2005; Kellerer-Pirklbauer, 2008; Scapozza et al., 2011b) and in Iceland (e.g. Kellerer-Pirklbauer et al., 2008), which report ages generally of between 6.0 and $3.0 \mathrm{ka} \mathrm{cal} \mathrm{BP.}$

SHD provides centennial to millennial variations of velocity representing the long-term speed of the rock glacier under partial steady-state climate conditions as reflected by the global climate trend. The limited number of locations where SHD was applied has the consequence that only the effects of major climate change periods, for example Medieval Warm Period (MWP) and post-LIA related warming, can be detected in the long-term rock glacier kinematics. An increase in the number of SHD locations in order to obtain a more detailed image of the long-term speed variations is of course possible, but implies the risk of obtaining dating not differentiated at a significant level $(p>0.05)$.

\section{Long-term rock glacier kinematics}

Long-term rock glacier kinematics have relatively constant velocities from the period of development of the landform to c. 1.2/1.1 ka cal BP, followed by a slow increase in velocity until the beginnings of the twentieth century and with a significant acceleration during the last decade of the twentieth century. Isotope curves from Greenland show similar relatively constant behaviour (Figure 7B) from 6.0 to $1.0 \mathrm{ka}$ cal BP, with a slow decrease in $\delta^{18} \mathrm{O}$ [observable in particular in the North Greenland Ice Core Project (NGRIP) curve] indicating a cooling trend of the climate after the Mid-Holocene climate optimum usually known as Neoglaciation (Matthews and Dresser, 2008). In the Swiss Alps, this cooling trend is associated with a major reduction of glacial recession rates from $3.4 \mathrm{ka}$ cal BP, as well as an important glacier advance starting at the end of the Roman Period. From $1.5 \mathrm{ka}$ cal BP the Great Aletsch glacier reached the position of the maximum stage of AD 1859/1860 at least three additional times (Figure $7 \mathrm{C}$ ). The long-term horizontal surface velocities of about 7-10 $\mathrm{cm} / \mathrm{a}$ for the period before the Middle Ages are of the same magnitude of inferred longterm velocities of other rock glaciers as determined by 

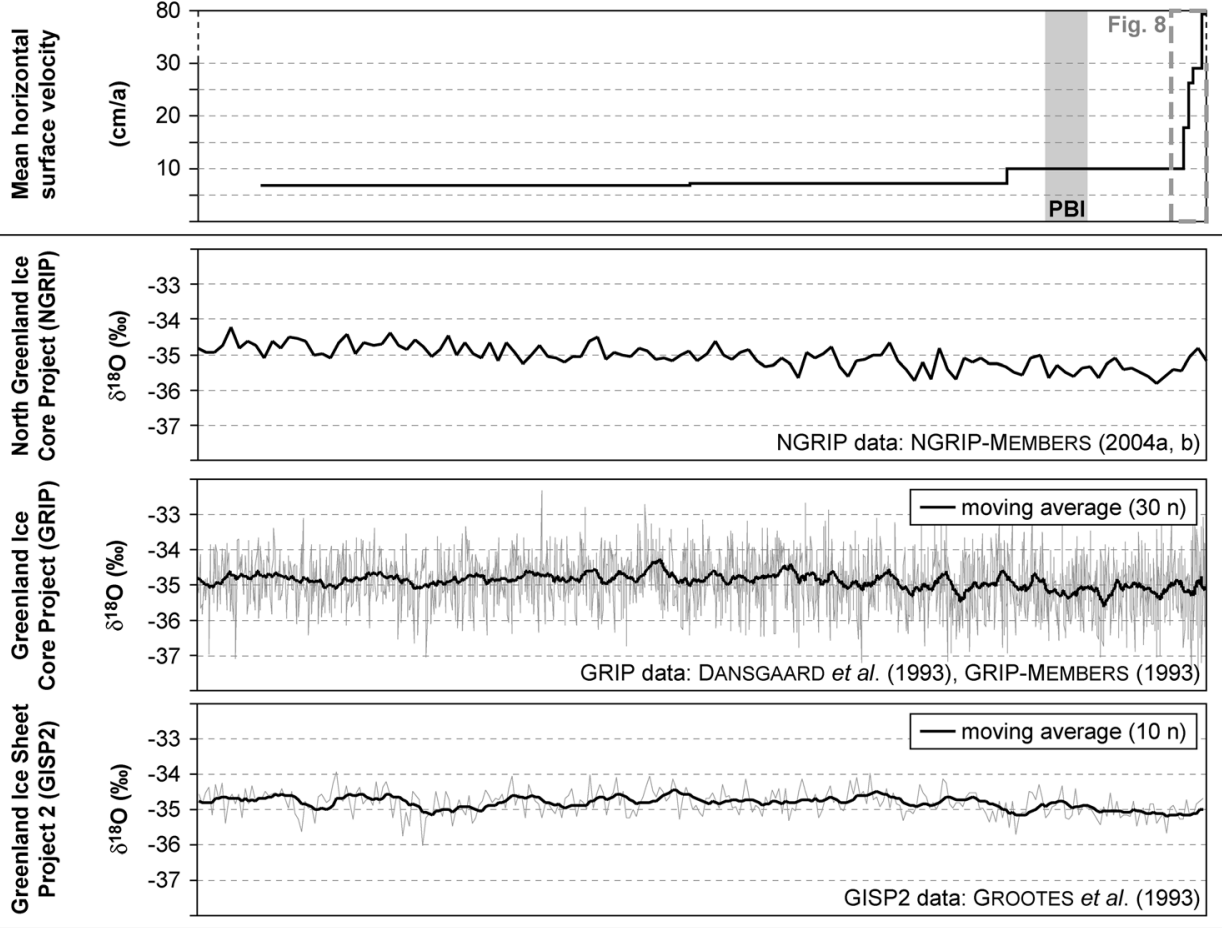
Creat Aletsch glacier fluctuations
over the last 3500 years established by HOLZHAUSER et al. (2005)

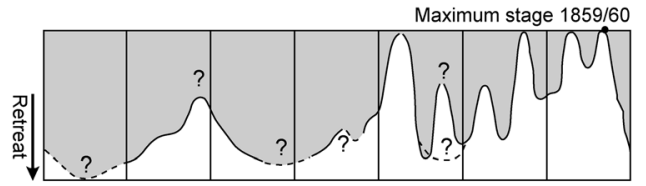

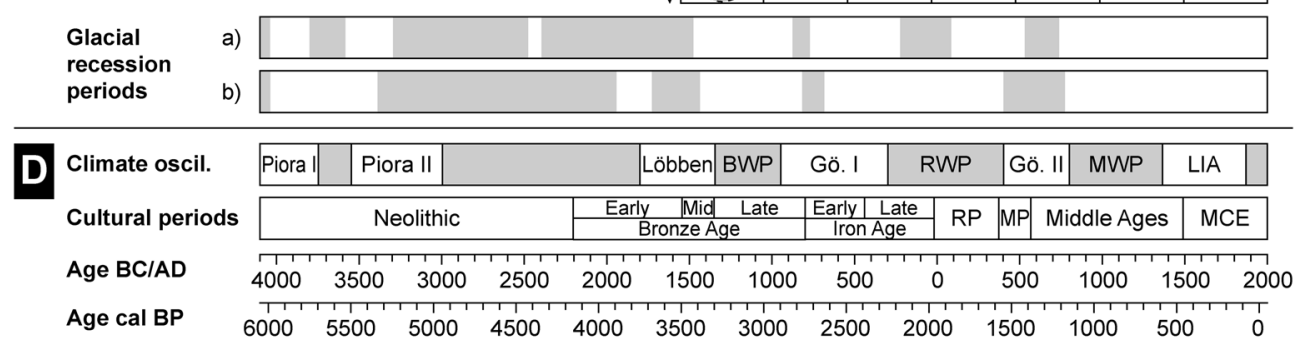

Figure 7. Comparison between the multi-temporal kinematics of the Stabbio di Largario rock glacier and several Holocene climate proxies for the last $6.0 \mathrm{ka}$. (A) Compilation of the mean horizontal surface velocities determined thanks to the SHD and to the WSL-Monoplotting-tool. The Piancabella rock glacier inactivation (PBI) interval shows the dating of inactivation of the Piancabella rock glacier according to Scapozza et al. (2010). (B) Oxygen isotopes variations according to the NGRIP, GRIP and GISP2 curves. (C) Glacier fluctuations in the Swiss Alps. Glacial recession periods (shaded) from Jörin et al. (2006) (a) and from Hormes et al. (2001) (b). (D) Chronological and climatic framework of the second half of the Holocene. Climate oscillations from Scapozza (2013), with warm/dry periods shaded and cold/moist periods in light: BWM=Bronze Warm Period; Gö. = Göschenen; RWP = Roman Warm Period; MWP = Medieval Warm Period; LIA = Little Ice Age. Cultural periods from Tinner et al. (2003): $\mathrm{RP}=$ Roman Period; $\mathrm{MP}=$ Migration Period; $\mathrm{MCE}=$ Modern and Contemporary Epoch.

exposure-age dating (in particular by lichenometry), for instance 1-7 cm/a for Svalbard (André, 1994), under much colder temperature conditions, $7-33 \mathrm{~cm} / \mathrm{a}$ for Canada (Sloan and Dyke, 2004), and 1-14 cm/a for the Alps in the Valais under temperature conditions similar to those of the southern Swiss Alps (Scapozza, 2013).

The first evidence of increases in long-term velocities is reported for the beginning of the MWP (c. AD 800/900 to AD 1250/1300 according to Mann et al., 2009), due to a relatively warm and dry period preceding the LIA cooling period. For the Piancabella site, located only $3 \mathrm{~km}$ southeast of the Stabbio di Largario rock glacier, a radiocarbon dating of larch (Larix decidua) sub-fossil logs from the base of the rock glacier front shows that during the end of the MWP (radiocarbon dating UZ-5545/ETH-34417 at 895-795 ${ }^{14} \mathrm{C} \mathrm{BP}=\mathrm{AD} 1040-1280$ ) the mean summer temperature was $1.2{ }^{\circ} \mathrm{C}$ higher than in $\mathrm{AD} 1950$ (Scapozza et al., 2010); this probably caused the inactivation of the Piancabella rock glacier.

During the MWP and the LIA the horizontal surface velocity remained stable at around $10 \mathrm{~cm} / \mathrm{a}$. In the southern Swiss Alps, the LIA was characterized by a marked glacial advance in particular during the period between AD 1590 and 1850 (Pellegrini, 1973). During this period (and probably also during the cold climate oscillation of Göschenen II preceding the MWP) the rooting zone of the Stabbio di Largario rock glacier was occupied by a small cirque glacier. The depression in the rooting zone represents the morphological trace of this glacier, which disappeared during the twentieth century. The clear pre-LIA exposure-age revealed by the SHD allows us to exclude the involvement of ice during the last $1.5 \mathrm{ka}$ glacial advances in the post-LIA rock glacier kinematics (see Avian et al., 2005, for a similar case in Austria Central Alps). Thus, the acceleration of the rock glacier during the first decades of the twentieth century (from c. $10 \mathrm{~cm} / \mathrm{a}$ in AD 1909 to c. $30 \mathrm{~cm} / \mathrm{a}$ in $\mathrm{AD} 1941$; Figure $8 \mathrm{~A}$ ) may be interpreted as a consequence of the significant supply of liquid water due to the melting of the glacier. Indeed, water circulation in the ground can have a considerable influence on the creeping dynamics of a rock glacier (Ikeda et al., 2008; Lambiel, 2011). This acceleration 

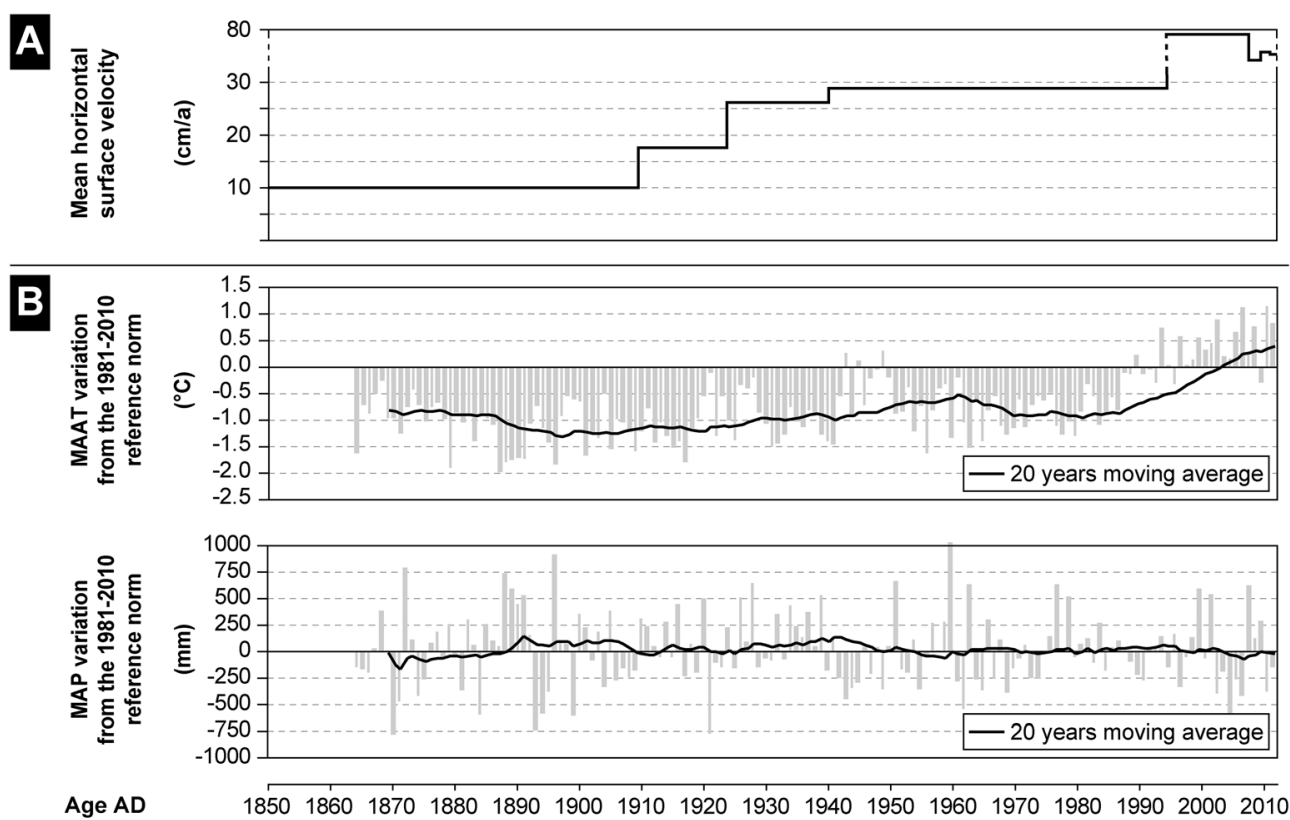

Figure 8. Comparison between the multi-temporal kinematics of the Stabbio di Largario rock glacier and climate parameters since AD 1850. (A) Compilation of the mean horizontal surface velocities obtained from the WSL-Monoplotting-tool and the dGPS monitoring. (B) Homogeneous mean annual air temperature (MAAT) and mean annual precipitation (MAP) of the MeteoSwiss station of Lugano from 1864 to 2012. Data from Begert et al. (2005).

may also be related to a warming of about $0.8{ }^{\circ} \mathrm{C}$ of MAAT between $A D 1900$ and 1960 and to MAP higher than the AD 1981-2010 norm in the periods AD 1888-1910 and AD 1926-1954 in particular (Figure 8B).

For the end of the twentieth century, the strong acceleration from c. $30 \mathrm{~cm} / \mathrm{a}$ in AD 1996 to velocities higher than $50 \mathrm{~cm} / \mathrm{a}$ in the followings years of the Stabbio di Largario rock glacier can be related to recent warming. MAAT in the southern Swiss Alps have warmed on average by $+1.3{ }^{\circ} \mathrm{C}$ between AD 1987 and 2012, with 18 out of 35 years warmer than the $A D$ 1981-2010 norm (Figure 8B). The acceleration of the rock glacier is also visible on InSAR images derived from the comparison of interferograms produced by satellites ERS-1 and ERS-1 (Mari et al., 2011). The interferogram derived from image acquisition on 31 July and 4 September 1998 (34 days of separation) at the Stabbio di Largario rock glacier shows a coherent image revealing movements lower than $3 \mathrm{~cm} /$ month (corresponding to the half of the wavelength) for the tongue of the rock glacier and a decorrelated image showing movements higher than $3 \mathrm{~cm} /$ month for the depression located in the rooting zone, probably related to the melting of the perennial ice patches (Ramelli et al., 2011). This corresponds for summer 1998 to low velocity (maximum $20 \mathrm{~cm} / \mathrm{a}$ ) sensu Lambiel et al. (2008) at the tongue of the rock glacier, and medium velocity $(20-100 \mathrm{~cm} / \mathrm{a})$ at the rooting zone. The difference between the mean horizontal surface velocity measured by dGPS between 2009 and 2012 for the median and the frontal part of the rock glacier (30 and $53 \mathrm{~cm} / \mathrm{a}$ with an associated vertical movement of 18 to $27 \mathrm{~cm} / \mathrm{a})$ and the rooting zone $(10 \mathrm{~cm} / \mathrm{a}$ with a vertical movement of 6 to $11 \mathrm{~cm} / \mathrm{a}$ ) (S. Mari, 2013, unpublished data) and the magnitude of movements revealed by the InSAR data confirms an acceleration of the tongue of the rock glacier since AD 1998, which is perfectly in line with the data obtained by the monophotogrammetric approach.

This significant speed-up of the rock glacier since the end of the 1990s is consistent with the behaviour of most European Alpine rock glaciers (e.g. Avian et al., 2005; Kääb et al., 2007; Delaloye et al., 2008, 2010). An acceleration is usually related to the recent increase of air and permafrost temperatures, which, in some cases, has already caused a destabilization of the entire landform (e.g. Roer et al., 2008; Lambiel, 2011; Delaloye et al., 2013). This is not yet the case for the Stabbio di Largario rock glacier thanks to rather slow creeping velocities. Nevertheless, the presence on the rock glacier tongue of several small transversal crevasses and of a large, some tens of metres long, longitudinal crevasse (Figure 1D) can be the morphological sign of an incipient destabilization of the rock glacier, which may evolve in future from a deformation-driven body to a sliding body. Indeed, the presence of crevasses may encourage the liquid water infiltration and then have an effect on the speed up of the rock glacier (Ikeda et al., 2008; Lambiel, 2011), creating a positive feedback between the degree of instability and velocity.

\section{Conclusions}

Four main conclusions can be drawn from the assessment of the kinematics of the Stabbio di Largario rock glacier on three different timescales proposed in this contribution. First, the extrapolated exposure-age (i.e. minimal age) of the front of the rock glacier of $5.05 \pm 0.57 \mathrm{ka}$ cal BP indicates that the Stabbio di Largario rock glacier started to develop during or just after the end of the Mid-Holocene climate optimum (9.5-6.3 ka cal BP). Second, an acceleration took place during the MWP, which was characterized in the southern Swiss Alps by summer temperatures $1.2{ }^{\circ} \mathrm{C}$ higher than in AD 1950 and which also caused important changes in dynamics, rheological properties and thermal conditions of the neighbouring Piancabella rock glacier (cf. Scapozza et al., 2010). Third, a subsequent acceleration occurred after the end of the LIA as a reaction to a warming of MAAT and an increase in MAP during the first half of the twentieth century (regional parameter), and probably also as a consequence of the melting of the glacier that occupied its rooting zone (local parameter). Finally, a significant acceleration has taken place since the late 1990s as the consequence of severe recent warming, resulting in the first signs of possible destabilization of the Stabbio di Largario rock glacier, such as the formation of crevasses on the rock glacier tongue. 
These results highlight an existing relationship between periods of increase in mean air temperature on different timescales and phases of rock glacier acceleration. If the second and third points mentioned earlier are concerned with regional-scale and local-scale responses of the Stabbio di Largario rock glacier to climate variations and, partially, to glaciological constraints, the first and fourth represent a response to continental- and global-scale climate signals. All four points have, however, the common trait of linking phases of rock glacier acceleration to increases in mean air temperature since the Mid-Holocene climate optimum. Furthermore, our findings indicate that these insights into the creep mechanisms of rock glaciers are not only present on a short-term scale (e.g. Kääb et al., 2007), but also on the long-term scale of rock glacier development and evolution (i.e. the scale of high mountain landscape evolution).

From a methodological point of view, this work has highlighted the importance of combining different surveying methods. Indeed, the first three points listed earlier could be defined by an approach combining millennial (defined by SHD) and centennial to decadal (defined by monophotogrammetry) creeping fluctuations. The use of the WSL-Monoplotting-tool has allowed for a more precise assessment of rock glacier velocities during the last century. Nevertheless, this particular case study permitted us to underline some problems related to the application of a current DTM subjected to alterations due to rock glacier advances in reconstructing past elements of the landscape. The main problems were related to the alteration of the DTM caused by the rock glacier advance, and to the production of large location errors in the case of DTM interception with quite a large angle from nadir, which is a general problem of monoscopic terrestrial photographs. Despite these problems, it was shown that the application of monophotogrammetry allows us to go back several decades more in time (at least to the beginnings of the twentieth century) as opposed to the classical stereophotogrammetry. It is therefore desirable to consider this tool as either a valid alternative or an important complement to traditional aerial photogrammetry in the future.

Acknowledgements - A part of this study makes the framework of the $\mathrm{PhD}$ thesis of Cristian Scapozza, which was supported by the Institute of Geography and Durability of the University of Lausanne. The dGPS monitoring of the Stabbio di Largario rock glacier was funded by the Swiss Permafrost Monitoring Network PERMOS. The monoplotting analysis of historical photographs was funded by the Swiss Federal Research Institute WSL in Bellinzona. A special thanks to the assistant editor, Dr Fiona Kirkby, and to the two anonymous reviewers for their useful feedback, as well as James Kaufmann for proofreading the English.

\section{References}

André M-F. 1994. Rock glaciers in Svalbard. Tentative dating and inferred long-term velocities. Geografiska Annaler 76A: 235-245.

Avian M, Lieb G, Kaufmann V. 2005. Recent and Holocene dynamics of a rock glacier system: the example of Langtalkar (Central Alps, Austria). Norsk Geografisk Tidsskrift 59: 149-156. DOI. 10.1080/ 00291950510020637

Barsch D. 1996. Rockglaciers. Indicators for the Present and Former Geoecology in High Mountain Environments. Springer: Berlin/Heidelberg; $331 \mathrm{pp}$.

Begert M, Schlegel T, Kirchhofer W. 2005. Homogeneous temperature and precipitation series of Switzerland from 1864 to 2000. International Journal of Climatology 25: 65-80. DOI. 10.1002/joc.1118

Bodin X, Thibert E, Fabre D, Ribolini A, Schoeneich P, Francou B, Reynaud L, Fort M. 2009. Two decades of responses (1986-2006) to climate by the Laurichard rock glacier, French Alps. Permafrost and Periglacial Processes 20: 331-344. DOI. 10.1002/ppp.665
Bozzini C, Conedera M, Krebs P. 2012. A new monoplotting tool to extract georeferenced vector data and orthorectified raster data from oblique non-metric photographs. International Journal of Heritage in the Digital Era 1: 499-518. DOI. 10.1260/2047-4970.1.3.499

Burga CA, Perret R, Zoller H. 2001. Swiss localities of early recognized Holocene climate oscillations - characterisation and significance. Vierteljahrsschrift der Naturforschenden Gesellschaft in Zürich 146: 65-74. Calderoni G, Guglielmin M, Lozej A, Tellini C. 1993. Research on rock glaciers in the Central Italian Alps (Valtellina, Sondrio, Northern Italy). In Proceedings of the 6th International Conference on Permafrost, Beijing, China, 5-9 July 1993, Guangzhou W (ed.). South China University of Technology Press: Beijing; 72-77.

Conedera M, Bozzini C, Scapozza C, Rè L, Ryter U, Krebs P. 2013. Anwendungspotenzial des WSL-Monoplotting-Tools im Naturgefahrenmanagement. Schweizerische Zeitschrift für Forstwesen. DOI. 10.3188/szf.2013.0173

Dansgaard W, Johnsen SJ, Clausen HB, Dahl-Jensen D, Gundestrup NS, Hammer CU, Hvidberg CS, Steffensen JP, Sveinbjörnsdóttir AE, Jouzel J, Bond GC. 1993. Evidence for general instability of past climate from a $250 \mathrm{kyr}$ ice-core record. Nature 264: 218-220. DOI. $10.1038 / 364218 \mathrm{a} 0$

Delaloye R, Lambiel C, Roer I. 2010. Overview of rock glacier kinematics research in the Swiss Alps. Seasonal rhythm, interannual variations and trends over several decades. Geographica Helvetica 65: 135-145. DOI. 10.5167/uzh-38562

Delaloye R, Morard S, Barboux C, Abbet D, Gruber V, Riedo M, Gachet S. 2013. Rapidly moving rock glaciers in Mattertal. In Mattertal - ein tal in Bewegung. Publikation zur Jahrestagung der Schweizerischen Geomorphologischen Gesellschaft 29. Juni-1. Juli 2011, St. Niklaus, Graf K. (ed). Eidg. Forschungsanstalt für Wald, Schnee und Landschaft WSL: Birmensdorf; 21-31. http://www.wsl.ch/dienstleistungen/ publikationen/buecher/12479/index_DE [23 May 2013].

Delaloye R, Perruchoud E, Avian M, Kaufmann V, Bodin X, Hausmann H, Ikeda A, Kääb A, Kellerer-Pirklbauer A, Krainer K, Lambiel C, Mihajlovic D, Staub B, Roer I, Thibert E. 2008. Recent interannual variations of rock glacier creep in the European Alps. In Proceedings of the 9th International Conference on Permafrost, Fairbanks, Alaska, 29 June-3 July 2009, Kane DL, Hinkel KM (eds). Institute of Northern Engineering, University of Alaska: Fairbanks; 343-348.

Dramis F, Giraudi C, Guglielmin M. (2003). Rock glacier distribution and paleoclimate in Italy. In Proceedings of the 8th International Conference on Permafrost, Zurich, Switzerland, 21-25 July 2003, Phillips M, Springman SM, Arenson LU (eds). Taylor \& Francis: Zurich; 199-204.

Evans DJ, Archer S, Wilson DJ. 1999. A comparison of the lichenometric and Schmidt hammer dating techniques based on data from the proglacial area of some Icelandic glaciers. Quaternary Science Reviews 18: 13-41. DOI. 10.1016/S0277-3791(98)00098-5

Frauenfelder R. 2005. Regional-scale modelling of the occurrence and dynamics of rockglaciers and the distribution of paleopermafrost. Schriftenreihe Physische Geographie, Glaziologie und Geomorphodynamik 45: 1-70.

Frauenfelder R, Kääb A. 2000. Towards a paleoclimatic model of rock glacier formation in the Swiss Alps. Annals of Glaciology 31: 281-286. DOI. 10.3189/172756400781820264.

Frauenfelder R, Laustela M, Kääb A. 2005. Relative age dating of alpine rockglacier surface. Zeitschrift für Geomorphologie N.F. 49: 145-166.

Galster F, Cavargna-Sani M, Epard J-L, Masson H. 2012. New stratigraphic data from the Lower Penninic between the Adula nappe and the Gotthard massif and consequences for the tectonics and the paleogeography of the Central Alps. Tectonophysics 579: 37-55. DOI. 10.1016/j.tecto.2012.05.029

Goudie AS. 2006. The Schmidt hammer in geomorphological research. Progress in Physical Geography 30: 703-718. DOI. 10.1177/ 0309133306071954

GRIP-Members. 1993. Climate instability during the last interglacial period recorded in the GRIP ice core. Nature 364: 203-207. DOI. 10.1038/364203a0

Grootes PM, Stuiver M, White JWC, Johnsen SJ, Jouzel J. 1993. Comparison of oxygen isotope records from the GISP2 and GRIP Greenland ice cores. Nature 366: 552-554. DOI. 10.1038/366552a0

Haeberli W, Hallet W, Arenson L, Elconin R, Humlum O, Kääb A, Kaufmann V, Ladanyi B, Matsuoka N, Springmann S, Vonder MD. 
2006. Permafrost creep and rock glacier dynamics. Permafrost and Periglacial Processes 17: 189-214. DOl. 10.1002/ppp.561

Holzhauser H, Magny M, Zumbühl HJ. 2005. Glacier and lake-level variations in west-central Europe over the last 3500 years. The Holocene 15: 789-801. DOI. 10.1191/0959683605hl853ra

Hormes A, Müller BU, Schlüchter C. 2001. The Alps with little ice: evidence for eight Holocene phases of reduced glacier extent in the Central Swiss Alps. The Holocene 11: 255-265. DOI. 10.1191/ 095968301675275728

Humlum O. 1988. Rock glacier appearance level and rock glacier initiation line altitude: a methodological approach to the study of rock glaciers. Arctic and Alpine Research 20: 160-178.

Humlum O. 2000. The geomorphic significance of rock glaciers: estimates of rock glacier debris volumes and headwall recession rates in West Greenland. Geomorphology 35: 41-67. DOI. 10.1016/ S0169-555X(00)00022-2

Ikeda A, Matsuoka N, Kääb A. 2008. Fast deformation of perennially frozen debris in a warm rock-glacier in the Swiss Alps: an effect of liquid water. Journal of Geophysical Research 113: F01021. DOI. 10.1029/2007JF000859

Jörin UE, Stocker TF, Schlüchter C. 2006. Multicentury glacier fluctuations in the Swiss Alps during Holocene. The Holocene 16: 687-704. DOI. 10.1191/0959683606hl964rp

Kääb A. 2005. Remote sensing of mountain glaciers and permafrost creep. Schriftenreihe Physische Geographie, Glaziologie und Geomorphodynamik 48: 1-264.

Kääb A, Frauenfelder R, Roer I. 2007. On the response of rockglacier creep to surface temperature increase. Global and Planetary Change 56: 172-187. DOI. 10.1016/j.gloplacha.2006.07.005

Kellerer-Pirklbauer A. 2008. The Schmidt-hammer as a relative age dating tool for rock glacier surfaces: examples from Northern and Central Europe. In Proceedings of the 9th International Conference on Permafrost, Fairbanks, Alaska, 29 June-3 July 2009, Kane DL, Hinkel KM (eds). Institute of Northern Engineering, University of Alaska: Fairbanks; 913-918.

Kellerer-Pirklbauer A, Wangensteen B, Farbrot H, Etzelmüller B. 2008. Relative surface age-dating of rock glacier systems near Hólar in Hjaltadalur, northern Iceland. Journal of Quaternary Science $\mathbf{2 3}$ 137-151. DOI. 10.1002/jqs.1117

Lambiel C. 2011. Le glacier rocheux déstabilisé de Tsaté-Moiry: caractéristiques morphologiques et vitesses de déplacement. In La géomorphologie alpine: entre patrimoine et contrainte. Actes du colloque de la Société Suisse de Géomorphologie, 3-5 septembre 2009, Olivone, Lambiel C, Reynard E, Scapozza C (eds). Institut de géographie de I'Université de Lausanne: Lausanne. Géovisions 36 : 211-224. http://www.unil.ch/igul/page84172.html [23 May 2013].

Lambiel C, Delaloye R. 2004. Contribution of real-time kinematics GPS in the study of creeping mountain permafrost: examples from the Western Swiss Alps. Permafrost and Periglacial Processes 15: 229-241. DOI. 10.1002/ppp.496

Lambiel C, Delaloye R, Strozzi T, Lugon R, Raetzo H. 2008. ERS InSAR for assessing rock glacier activity. In Proceedings of the 9th International Conference on Permafrost, Fairbanks, Alaska, 29 June-3 July 2009, Kane DL, Hinkel KM (eds). Institute of Northern Engineering, University of Alaska: Fairbanks; 1019-1024.

Little JD, Sandall H, Walegur MT, Nelson FE. 2003. Application of differential global positioning systems to monitor frost heave and thaw settlement in Tundra environments. Permafrost and Periglacial Processes 14: 349-357. DOI. 10.1002/ppp.466

Maisch M. 1992. Die Gletschers Graubündens. Teil B: Verzeichnisse, Datenkataloge, Gletscherkarten. Physische Geographie 33: 1-128.

Mann ME, Zhang Z, Rutherford S, Bradley RS, Hughes MK, Shindell D, Ammann C, Faluvegi G, Fenbiao N. 2009. Global signatures and dynamical origins of the Little Ice Age and Medieval Climate Anomaly. Science 326: 1256-1260. DOI. 10.1126/science.1177303

Mari S, Delaloye R, Scapozza C, Strozzi T. 2011. Inventario dei movimenti di terreno per analisi dei segnali InSAR nelle Alpi meridionali svizzere (periodo 1994-2007). In La géomorphologie alpine: entre patrimoine et contrainte. Actes du colloque de la Société Suisse de Géomorphologie, 3-5 septembre 2009, Olivone, Lambiel C, Reynard E, Scapozza C (eds). Institut de géographie de l'Université de Lausanne: Lausanne. Géovisions 36: 145-159. http://www.unil. ch/igul/page84172.html [23 May 2013].
Matthews JA, Dresser PQ. 2008. Holocene glacier variation chronology of the Smørstabbtindan massif, Jotunheimen, southern Norway, and the recognition of century- to millennial-scale European Neoglacial Events. The Holocene 18: 181-201. DOI. 10.1177/ 0959683607085608

Matthews JA, Owen G. 2010. Schmidt hammer exposure-age dating: developing linear age-calibration curves using Holocene bedrock surfaces from the Jotunheimen-Jostedalsbreen regions of southern Norway. Boreas 39: 105-115. DOI. 10.1111/j.15023885.2009.00107.x

Matthews JA, Shakesby RA, Owen G, Vater AE. 2011. Pronival rampart formation in relation to snow-avalanche activity and Schmidthammer exposure-age dating (SHD): three case studies from southern Norway. Geomorphology 130: 280-288. DOI. 10.1016/j. geomorph.2011.04.010

McCarroll D. 1989. Potential and limitations of the Schmidt Hammer for relative-age dating: field tests on Neoglacial moraines, Jotunheimen, Southern Norway. Arctic and Alpine Research 21: 268-275.

NGRIP-Members. 2004a. High resolution record of Northern Hemisphere climate extending into the last interglacial period. Nature 431: 147-151. DOI. 10.1038/nature02805

NGRIP-Members. 2004b. North Greenland Ice Core Project Oxygen Isotope Data. IGBP PAGES/World Data Center for Paleoclimatology Data Contribution Series n. 2004-059. NOAA/NGDC Paleoclimatology Program: Boulder, CO.

Pellegrini M. 1973. Materiali per una storia del clima nelle Alpi Lombarde durante gli ultimi cinque secoli. Archivio Storico Ticinese 55(56): 133-278.

PERMOS. 2010. Permafrost in Switzerland 2006/2007 and 2007/2008 Noetzli J, Vonder Mühll D (eds), Glaciological Report Permafrost No. 8/9 of the Cryospheric Commission of the Swiss Academy of Sciences. University of Zurich: Zurich; 68 pp.

Ramelli G, Scapozza C, Mari S, Lambiel C. 2011. Structure interne et dynamique des glaciers rocheux du massif de la Cima di Gana Bianca, Val Blenio (Tessin). In La géomorphologie alpine: entre patrimoine et contrainte. Actes du colloque de la Société Suisse de Géomorphologie, 3-5 septembre 2009, Olivone, Lambiel C, Reynard E, Scapozza C (eds). Institut de géographie de l'Université de Lausanne: Lausanne. Géovisions 36: 177-193. http://www.unil.ch/igul/ page84172.html [23 May 2013].

Roer I, Kääb A, Dikau R. 2005. Rockglacier kinematics derived from small-scale aerial photography and digital airborne pushbroom imagery. Zeitschrift für Geomorphologie N.F. 49: 73-87.

Roer I, Haeberli W, Avian M, Kaufmann V, Delaloye R, Lambiel C, Kääb A. 2008. Observations and considerations on destabilizing active rock glaciers in the European Alps. In Proceedings of the 9th International Conference on Permafrost, Fairbanks, Alaska, 29 June-3 July 2009, Kane DL, Hinkel KM (eds). Institute of Northern Engineering, University of Alaska: Fairbanks; 1505-1510.

Scapozza C. 2013. Stratigraphie, morphodynamique, paléoenvironnements des terrains sédimentaires meubles à forte déclivité du domaine périglaciaire alpin. Institut de géographie et durabilité de I'Université de Lausanne: Lausanne. Géovisions 40: 1-551. http:// www.unil.ch/igul/page96426.html [23 May 2013].

Scapozza C, Fontana G. 2009. Le Alpi Bleniesi. Storia glaciale e periglaciale e patrimonio geomorfologico. Memorie della Società ticinese di Scienze naturali e del Museo cantonale di storia naturale, Lugano 10: 1-111.

Scapozza C, Lambiel C, Gex P, Reynard E. 2011a. Prospection géophysique multi-méthodes du pergélisol alpin dans le Sud des Alpes Suisses. Géomorphologie: relief, processus, environnement 1 (2011): 15-32. DOI. 10.4000/geomorphologie.8765

Scapozza C, Lambiel C, Reynard E. 2011b. Datation relative de formes périglaciaires alpines à l'aide de la méthode paléogéographique et du marteau de Schmidt. In La géomorphologie alpine: entre patrimoine et contrainte. Actes du colloque de la Société Suisse de Géomorphologie, 3-5 septembre 2009, Olivone, Lambiel C, Reynard E, Scapozza C (eds). Institut de Géographie de I'Université de Lausanne: Lausanne. Géovisions 36: 127-143. http://www.unil.ch/igul/ page84172.html [23 May 2013].

Scapozza C, Lambiel C, Reynard E, Fallot J-M, Antognini M, Schoeneich P. 2010. Radiocarbon dating of fossil wood remains buried by the Piancabella rock glacier, Blenio Valley (Ticino, Southern Swiss Alps): 
implications for rock glacier, treeline and climate history. Permafrost and Periglacial Processes 21: 90-96. DOI. 10.1002/ppp.673

Schmidt E. 1950. Der Beton-Prüfhammer - Ein Gerät zur Bestimmung der Qualität des Betons im Bauwerk. Schweizerische Bauzeitung 68: 378-379.

Shakesby RA, Matthews JA, Karlén W, Los SO. 2011. The Schmidt hammer as a Holocene calibrated-age dating technique: testing the form of the R-value-age relationship and defining the predicted-age error. The Holocene 21: 615-628. DOI. 10.1177/0959683610391322

Shakesby RA, Matthews JA, Owen G. 2006. The Schmidt hammer as a relative-age dating tool and its potential for calibrated-age dating in Holocene glaciated environments. Quaternary Science Reviews 25: 2846-2867. DOI. 10.1016/j.quascirev.2006.07.011

Sloan VF, Dyke LD. 2004. Decadal and millennial velocities of rock glaciers, Selwyn Mountains, Canada. Geografiska Annaler 80A: 237-249. DOI. 10.1111/j.0435-3676.1998.00040.x

Solari L 1998. Blenio: una valle a confronto. Salvioni Arti Grafiche: Bellinzona; 183 pp.

Stahl T, Winkler S, Quigley M, Bebbington M, Duffy B, Duke D. 2013. Schmidt hammer exposure-age dating (SHD) of late Quaternary fluvial terraces in New Zealand. Earth Surface Processes and Landforms 38: 1838-1850. DOI. 10.1002/esp.3427

Strozzi T, Kääb A, Frauenfelder R. 2004. Detecting and quantifying mountain permafrost creep from in situ inventory, space-borne radar interferometry and airborne digital photogrammetry. International Journal of Remote Sensing 25: 2919-2931. DOI. 10.1080/ 0143116042000192330

Tinner W, Lotter AF, Ammann B, Conedera M, Hubschmid P, van Leeuwen JFN, Wehrli M. 2003. Climatic change and contemporaneous land-use phases north and south of the Alps 2300 BC to 800 AD. Quaternary Science Reviews 22: 1447-1460. DOI. 10.1016/S02773791(03)00083-0

Winkler S. 2009. First attempt to combine terrestrial cosmogenic nuclide $\left({ }^{10} \mathrm{Be}\right)$ and Schmidt hammer relative-age dating: Strauchon Glacier, Southern Alps, New Zealand. Central European Journal of Geosciences 1: 274-290. DOI. 10.2478/v10085-009-0026-3

Zeller G. 1964. Morphologische Untersuchungen in den östlichen Seitentälern des Val Blenio. Beiträge zur Geologie der Schweiz Hydrologie 13: 1-111. 